\title{
Effects of castration on serum LH and FSH concentrations in male guinea-pigs
}

\author{
Dominique Croix
}

\author{
Laboratoire d'Histologie, Faculté de Médicine, Place de Verdun, 59045 Lille Cedex, France
}

The gonadotrophic hormones LH and FSH of guinea-pigs have complete specific cross-reaction with the corresponding rat hormones (Croix \& Franchimont, 1975) in heterologous systems of radioimmunological measurement comprising ovine anti-LH or anti-FSH sera (Niswender, Midgley, Monroe \& Reichert, 1968; Hendrick, Legros \& Franchimont, 1971). We have used these systems to show a dissociation of the discharge of FSH and LH during the oestrous cycle, particularly at the time of ovulation when the LH peak occurs well before that of FSH (Croix \& Franchimont, 1975), and during the postnatal period (Croix, 1976). The present study was an investigation of the effect of castrating guinea-pigs on the variations in serum concentrations of FSH and LH.

Tricolor male guinea-pigs aged 3 months, weighing $450 \mathrm{~g}$ and kept in constant lighting ( $14 \mathrm{~h}$ light / $24 \mathrm{~h}$ from $06.00 \mathrm{~h})$ and temperature $\left(22 \pm 2^{\circ} \mathrm{C}\right)$ conditions, were castrated bilaterally after anaesthesia by intraperitoneal injection of $0.85 \mathrm{ml} 20 \%$ urethane and $0.15 \mathrm{ml} \mathrm{Nembutal}$. Eleven animals died, mainly from infection, during the experimental period; the first deaths ( 2 animals) occurred 4 days after the operation. The remaining animals (124) were in good health when killed at $10.30 \mathrm{~h}$ by decapitation $24 \mathrm{~h}$ to 97 days after castration. The weight increases of the animals after castration were regular and linear (from $450 \pm 12$ (S.E.M.) g, $\mathrm{N}=124$, to $750 \pm 40 \mathrm{~g}, \mathrm{~N}=5$ ). The blood of each animal was collected separately, coagulated at $4^{\circ} \mathrm{C}$ and centrifuged. The sera were stored at $-20^{\circ} \mathrm{C}$ until measurement of LH and FSH by radioimmunoassay. The hormonal preparations used for labelling (NIAMD-rat-LH-I1 and NIAMD-rat-FSH-I1) and for establishing the standard curves (NIAMD-rat-LH-RP1 and NIAMD-rat-FSH-RP1) were provided by NIAMDD, National Institutes of Health, Bethesda, Maryland, U.S.A. The antisera were prepared in rabbits by immunization against ovine LH (NIH-LH-S15) (Dufy-Barbe, Hendrick, Franchimont \& Faure, 1972) and ovine FSH (SH 80820: Schering) (Hendrick et al., 1971). Labelling with $\mathrm{Na}^{125} \mathrm{I}$ (CEA, Gif sur Yvette) was carried out by the chloramine $T$ method (Greenwood, Hunter \& Glover, 1963) and the labelled hormone was separated from the radioactive salts by gel filtration on Sephadex G50 medium. All stages of the radioimmunological measurements (double precipitation method) were performed at laboratory temperature. Dilutions were effected in Sorensen $0.05 \mathrm{M}$-sodium phosphate buffer $(\mathrm{pH}$ 7.5 ) containing $0.5 \%$ bovine serum albumin and $0.05 \%$ sodium azide,

A sample $(0.2 \mathrm{ml})$ of the reference hormone solution at different concentrations or of the serum to be measured was added to the relevant antiserum, diluted at $1: 8000$ for LH and $1: 1000$ for FSH. After a minimum of $4 \mathrm{~h}$ for establishing balance, $0 \cdot 1 \mathrm{ml}$ diluted labelled hormone (or about 20,000 $\mathrm{ct} / \mathrm{min}$ ) was added. After incubation for $24 \mathrm{~h}, 0 \cdot 1 \mathrm{ml}$ normal rabbit serum diluted at $1: 100$ and $0 \cdot 1 \mathrm{ml}$ anti-rabbit gammaglobulin, obtained from sheep (Wellcome Laboratories) and diluted at $1: 10$, were added. Following further incubation for $16 \mathrm{~h}$, the precipitate in each tube was washed in $2.5 \mathrm{ml}$ buffer. The tubes were then centrifuged for $15 \mathrm{~min}$ at $2500 \mathrm{~g}$; the supernatant was removed by aspiration and the radioactivity of the precipitate counted. Triplicate assays were performed for the standard curve and duplicate assays for the sera. All sera were measured during the same experiment to avoid interassay variation.

In the absence of unlabelled hormone, labelled rat $\mathrm{LH}$ gave $26 \%$ binding to the anti-ovine $\mathrm{LH}$ antibody and the coefficient of the intra-assay variation was $2 \cdot 8 \%$. Labelled rat FSH gave $22 \%$ binding to the anti-ovine FSH antibody and the coefficient of the intra-assay variation was $3 \%$. As the cross-reaction between rat and guinea-pig hormones was complete for measurement of LH and FSH (see Croix \& Franchimont, 1975) theresults were expressed in terms of the NIAMDstandard rat hormones. Serial dilution curves were performed with sera from intact and castrated animals and 
Table 1. Effects (mean \pm S.E.M.) of castration on serum $\mathrm{LH}$ and FSH levels (ng/ml) in male guinea-pigs (no. in parentheses)

\begin{tabular}{|c|c|c|c|c|c|}
\hline $\begin{array}{l}\text { Days } \\
\text { after castration }\end{array}$ & LH & FSH & $\begin{array}{c}\text { Days } \\
\text { after castration }\end{array}$ & LH & FSH \\
\hline 0 & $1.7 \pm 0.2(16)$ & $90 \pm 5(15)$ & 18 & $36 \cdot 0 \pm 6 \cdot 2(3)$ & $543 \pm 28(3)$ \\
\hline 1 & $1.7 \pm 0.9(5)$ & $226 \pm 18(5)$ & 21 & $9 \cdot 3 \pm 2 \cdot 2(6)$ & $670 \pm 66(5)$ \\
\hline 2 & $5.2 \pm 1.4(10)$ & $482 \pm 41(10)$ & 24 & $29 \cdot 7$ & $570 \quad$ (1) \\
\hline 4 & $12.8 \pm 7.0(8)$ & $536 \pm 43(8)$ & 28 & $45 \cdot 0 \pm 3 \cdot 5(3)$ & $965 \pm 167(4)$ \\
\hline 5 & $16.5 \pm 6.6(6)$ & $791 \pm 77(6)$ & 35 & $38 \cdot 2 \pm 2 \cdot 9(5)$ & $968 \pm 180(5)$ \\
\hline 6 & $11.9 \pm 2.8(14)$ & $725 \pm 94(13)$ & 42 & $47 \cdot 0 \pm 8 \cdot 4(6)$ & $866 \pm 148(6)$ \\
\hline 8 & $14 \cdot 2 \pm 4 \cdot 4(8)$ & $941 \pm 132(8)$ & 52 & $39 \cdot 8 \pm 4 \cdot 2(5)$ & $865 \pm 152(5)$ \\
\hline 9 & $6.0 \pm 2.7(4)$ & $1065 \pm 195(4)$ & 62 & $32 \cdot 8 \pm 6 \cdot 2(5)$ & $1016 \pm 147(5)$ \\
\hline 10 & $16.0 \pm 5.5(8)$ & $1092 \pm 160(8)$ & 71 & $61.0 \pm 6.6(5)$ & $2030 \pm 184(5)$ \\
\hline 12 & $22 \cdot 0 \pm 11 \cdot 0(4)$ & $662 \pm 69(4)$ & 83 & $36 \cdot 0 \pm 4 \cdot 2(4)$ & $1310 \pm 117(4)$ \\
\hline 14 & $6.2 \pm 3.7(3)$ & $406 \pm 56(3)$ & 92 & $33 \cdot 7 \pm 5 \cdot 1(5)$ & $1310 \pm 117(5)$ \\
\hline 16 & $13.5 \pm 2.3(3)$ & $626 \pm 40(3)$ & Controls & $7 \cdot 2 \pm 0.5(3)$ & $111 \pm 8(3)$ \\
\hline
\end{tabular}

from pituitary extracts and they were parallel with the standard curves. The lowest detectable levels of LH and FSH in sera were $1 \mathrm{ng} / \mathrm{ml}$ and $4 \mathrm{ng} / \mathrm{ml}$, respectively. The results were analysed statistically by Student's $t$ test,

The results are shown in Table 1. The LH levels were variable during the first 3 weeks after castration and stabilized between 30 and $50 \mathrm{ng} / \mathrm{ml}$ at about 30 days. The serum LH concentrations in animals killed 92 days after castration were nearly 5 times greater $(P<0.02)$ than those in intact animals of the same age raised in the same conditions. FSH levels rose quickly until 10 days, then fell before increasing again more slowly (Table 1). At 92 days the serum FSH levels were 11.8 times greater $(P<0.001)$ in the castrated than in the non-castrated animals of the same age.

As in the rat, the castration of male guinea-pigs clearly affects serum LH and FSH levels. The serum LH levels increased only after a delay of $48 \mathrm{~h}$ and by progressively increasing oscillations, as in rats (Gay \& Sheth, 1972; Blake, 1974), which correspond to the changes of LH-RH load in hypothalamic cells observed by Barry, Dubois \& Poulain (1973) and Barry, Dubois \& Carette (1974) with immunofluorescent techniques. In ovariectomized rats, the discharge of LH-RH is also pulsatile and plasma LH-RH and LH levels are correlated (Wheaton \& McCann, 1976). The increase in LH levels is presumably due to the disappearance of the negative feedback exerted by testosterone on $\mathrm{LH}$ secretion (Demoulin, Thieblot \& Franchimont, 1973). The FSH levels increased much more rapidly and reached very high levels by 10 days after operation, as was found by Donovan et al. (1975a) and Donovan, Ter Haar, Lockhart \& Peddie (1975b). FSH secretion can be inhibited by intraperitoneal injection of a protein-like substance contained in seminal plasma, inhibin. This inhibition is selective towards FSH secretion (Franchimont, Chari \& Demoulin, 1975) and is probably derived from the germinal epithelium of the testis. After castration, the suppression of this type of negative feedback might be the essential cause of the increased FSH secretion, because testosterone has no effect on FSH secretion at low doses (Dufy-Barbe \& Franchimont, 1972).

The distinct dissociation of serum LH and FSH concentrations which we and others have observed in the guinea-pig during the oestrous cycle, after birth and after castration suggest specific, independent regulation of the secretion of each hormone. This double regulation might take place by means of hypothalamic activity through the existence of two different releasing factors.

This work was supported by a grant to Professor J. Barry from the D.G.R.S.T., project No. 74-7-0518.

\section{References}

Barry, J., Dubois, M.P. \& Poulan,, P. (1973) LRF producing cells of the mammalian hypothalamus. Z. Zellforsch. mikrosk. Anat. 146, 351-366.
Barry, J., Dubots, M.P. \& CaretTe, B. (1974) Immunofluorescence study of the preoptico-infundibular LRF neurosecretory pathway in normal, castrated 
and testosterone treated male guinea pig. Endocrinology 95, 1416-1423.

BlAKe, C.A. (1974) Localization of the inhibitory action of ovulation blocking drugs on release of luteinizing hormone in ovariectomized rats. Endocrinology 95, 999-1004.

Crorx, D. (1976) Variations des taux sériques de LH et de FSH durant la période post-natale chez le cobaye. C. r. hebd. Séanc. Acad. Sci., Paris 282, 649-651.

Croix, D. \& Franchimont, P. (1975) Changes in the serum levels of the gonadotrophins, progesterone and estradiol during the estrus cycle of the guinea pig. Neuroendocrinology 19, 1-11.

Demoulin, A., Thieblot, P. \& Franchimont, P. (1973) Influence de différents stéroides et de la prostaglandine $\mathrm{E}_{1}$ sur le taux des gonadotrophines sériques chez le rat male castré. C. r. Séanc. Soc. Biol. 167, 1684-1687.

Donovan, B.T., Ter HaAR, M.B., Lockhart, A.N., MacKmnon, P.C.B., MatTock, J.M. \& Peddie, M.J. (1975a) Changes in the concentration of luteinizing hormone in plasma during development in the guinea pig. J. Endocr. 64, 511-520.

Donovan, B.T., Ter HaAR, M.B., Lockhart, A.N. \& Peddie, M.J. (1975b) Changes in the concentration of follicle stimulating hormone in plasma during development in the guinea pig. J. Endocr. 64, 521-528.

Dufy-Barbe, L. \& Franchimont, P. (1972) Influence des différents stéroides gonadiques sur le taux de la FSH et de la LH chez le rat castré. C.r. Séanc. Soc. Biol. 166, 960-964.
Dufy-Barbe, L., Hendrick, J.C., Franchimont, P. \& FAURE, J.M.A. (1972) Dosage radioimmunologique par immunoadsorbant des gonadotrophines FSH et LH de lapin; applications physiologiques. Annls Endocr. 33, 481-491.

Franchimont, P., Chari, S. \& Demoulin, A. (1975) Hypothalamus-pituitary-testis interaction. J. $R e$ prod. Fert. 44, 335-350.

GAY, V.L. \& SHETH, N.A. (1972) Evidence for a periodic release of $\mathbf{L H}$ in castrated male and female rats. Endocrinology 90, 158-162.

Greenwood, F., Hunter, W. \& Glover, S. (1963) Preparation of ${ }^{131} \mathrm{I}$ labelled human growth hormone of high specific radioactivity. Biochem. J. 89, 114 121.

Hendrick, J.C., Legros, J.J. \& Franchimont, P. (1971) Le dosage radioimmunologique de la FSH de rat étude radioimmunologique de la réaction croisée entre la FSH de rat, de mouton et de porc. Annls Endocr. 32, 241-251.

Niswender, G.D., Midgley, A.R., Monroe, S.E. \& REICHERT, L.E. (1968) Radioimmunoassay for rat luteinizing hormone with antiovine $\mathrm{LH}$ serum and ovine LH ${ }^{131}$ I. Proc. Soc, exp. Biol. Med. 128, 807811.

WhEATON, J.E. \& MCCANN, S.M. (1976) Luteinizing hormone releasing hormone in peripheral plasma and hypothalamus of normal and ovariectomized rats. Neuroendocrinology 20, 296-310. 